\title{
Konsep Perlindungan Pengetahuan Tradisional Berdasarkan Asas Keadilan Melalui Sui Generis Intellectual Property System
}

\author{
Imas Rosidawati Wiradirja \\ Universitas Islam Nusantara Bandung \\ Jl. Soekarno Hatta No. 530 Bandung (022) 7507421 \\ i_rosida_df@yahoo.co.id
}

\begin{abstract}
This research aims to analyze and observe the answer for several issues: first, finding out the legal protection for Intellectual Property Rights in traditional science in consideration to the absence of a particular regulation in Indonesia laws; second, to find out a concept of equitable management of the traditional science in order to support the economic development in Indonesia. The approach used in this research refers to both judicial-normative method and judicial-comparative method. The result of the research then reveals the following conclusions: first, the protection for Intellectual Property Rights towards traditional science using the regulations of Intellectual Property Rights, in fact, cannot give a total protection. In essence, the protection of Intellectual Property Rights is exclusive, monopolistic, and individualistic making it to be privat domain. This is much different from the nature of traditional science more focused on collectivism. Second, the precise concept of traditional science management is by regulating the Sui Generis law that is by making prior art as a protection by accommodating the equitable concept of "benefit sharing". The existing regulation of Intellectual Property Rights after Indonesia ratified TRIPs cannot give any justice for the protection towards traditional science for the existence of misappropriation.
\end{abstract}

Key words : Traditional science, intellectual property rights, justice, sui generis

\begin{abstract}
Abstrak
Penelitian ini bertujuan untuk menganalisis dan menemukan jawaban atas beberapa permasalahan: pertama, menemukan perlindungan hukum Hak Kekayaan Intelektual dalam bidang pengetahuan tradisional; mengingat belum ada pengaturan yang khusus dalam perundang-undangan Indonesia. Kedua, untuk menemukan konsep pengelolaan pengetahuan tradisional yang berkeadilan dalam mendukung pembangunan ekonomi di Indonesia. Metode pendekatan yang digunakan yuridis normatif dan yuridis komparatif. Hasil penelitian menyimpulkan: pertama, perlindungan Hak Kekayaan Intelektual terhadap pengetahuan tradisional dengan memanfaatkan UU Hak Kekayaan Intelektual belum sepenuhnya dapat memberikan perlindungan. Dalam perlindungan HKI sesuai dengan sifatnya yang eksklusif, monopolis, individualistis sehingga bersifat privat domain sangat berbeda dengan sifat pengetahuan tradisional yang mengusung paham kolektifisme. Kedua, konsep pengelolaan pengetahuan tradisional yang tepat adalah dengan membuat undang-undang yang bersifat Sui Generis, dengan membuat dokumen pembanding (prior art) sebagai sarana perlindungan dengan mengakomodasi konsep "benefit sharing" yang berkeadilan. Peraturan HKI yang ada setelah Indonesia meratifikasi TRIPs tidak dapat memberikan keadilan bagi perlindungan terhadap pengetahuan tradisional dengan banyaknya misappropriation.
\end{abstract}

Kata Kunci : Pengetahuan tradisional, HKI, keadilan, sui generis 


\section{Pendahuluan}

Indonesia sudah meratifikasi perjanjian mengenai aspek-aspek perdagangan yang terkait dengan Hak Kekayaan Intelektual (Agreement on Trade Related Aspect of Intellectual Property Rights/TRIPs) dalam perjanjian Pembentukan Organisasi Perdagangan Dunia (Agreement Establishing the World Trade Organization). ${ }^{1}$ Konsekuensinya harus menyesuaikan prinsip-prinsip sebagaimana diatur dalam kesepakatan dunia itu, antara lain diperluasnya lingkup sistem Hak Kekayaan Intelektual (HKI) nasional. ${ }^{2}$

Di Indonesia salah satu kendala untuk dapat memberikan perlindungan HKI adalah dari masyarakat sendiri, yang di satu sisi masih menganggap HKI merupakan "public right"3 yang mempunyai fungsi sosial, karena masih banyak masyarakat yang tidak merasa keberatan apabila produk mereka ditiru oleh pihak lain. Kasus semacam ini dapat dijumpai di Bali. ${ }^{4}$ Masyarakat Bali tidak berkeberatan dengan adanya tindak peniruan tersebut, tetapi justru sebaliknya mereka merasa bangga, karena dengan ditirunya produk mereka, terdapat suatu anggapan bahwa produk tersebut menarik dan hebat. Sikap budaya masyarakat Indonesia yang belum memahami HKI secara sepenuhnya dan tidak didukung oleh kesadaran hukum yang memadai seringkali menyalahartikan bahwa perlindungan HKI tidak sejalan dengan budaya setempat. ${ }^{5}$

Masuknya TRIPs ${ }^{6}$ dalam WTO, memunculkan anggapan bahwa sistem HKI merupakan salah satu alat bagi negara maju untuk melindungi kepentingan

${ }^{1}$ Undang-Undang RI Nomor 7 Tahun 1994 tentang Pengesahan Agreement Establishing the World Trade Organization (Persetujuan Pembentukan Organisasi Perdagangan Dunia), disahkan dan diundangkan pada tanggal 2 November 1994 dalam Lembaran Negara RI Tahun 1994 Nomor 57.

${ }^{2}$ Pengelompokkan sistem HKI secara rinci menurut TRIPs didasarkan pada ketentuan Pasal 1 ayat (2) bahwa yang dimaksud dengan HKI meliputi semua kategori kekayaan intelektual sebagaimana dimaksud dalam BAB II Bagian 1 sampai dengan Bagian 7 Agreement TRIps. Lihat Achmad Zen Purba, Hak Kekayaan Intelektual Pasca TRIPs, Alumni, Bandung, 2005, hlm. 22.

${ }^{3}$ Cita Citrawinda Priapantja, Budaya Hukum Indonesia Menghadapi Globalisasi Perlindungan Rahasia Dagang di Bidang Farmasi, Chandra Pratama, Jakarta, 2005, hlm. 22. Dijelaskan bahwa di negara-negara berkembang lainnya seperti Cina, HKI seringkali dianggap sebagai suatu " $p$ ublic right'. Sebagai contoh, peniruan sampai sedetail-detailnya mengenai seni dan naskah-naskah tertulis dianggap sebagai bentuk penghormatan tertinggi kepada orang yang berkuasa.

${ }^{4}$ Ranti Fauza Mayana, Perlindungan Desain Industri di Indonesia, Grasindo, Jakarta, 2004, hlm.8.

${ }^{5}$ Sudjana, Perlindungan Desain Tata Letak Sirkuit Terpadu Dibubungkan dengan Daya Saing Industri Elektronika pada Era Perdagangan Bebas, disertasi, Universitas Padjadjaran, 2006, hlm.16. Konsep komunal mengakibatkan HKI bergaya barat sulit dimengerti oleh kebanyakan masyarakat adat Indonesia sehingga dimungkinkan bahwa HKI yang dianggap individualisme akan disalahartikan bahkan ditolak.

${ }^{6}$ Persetujuan TRIPs mulai berlaku tanggal 1 Januari 1995, tetapi bagi Indonesia Persetujuan TRIPs mulai berlaku efektif tanggal 1 Januari 2000, hal ini merujuk pada Pasal 65 Agreement on Trade Related Aspects of Intellectual Property Rights (TRIPs Agreement 1994), mengenai ketentuan-ketentuan peralihan bagi negara-negara berkembang, negara berkembang harus memberikan perlakuan yang sama dan memiliki kewajiban-kewajiban sampai tahun 2000 untuk melaksanakan kewajiban-kewajiban substantif lainnya. 
perdagangan mereka, anggapan ini tidak seluruhnya benar karena melalui sistem HKI kepentingan negara yang memiliki sumber daya alam akan turut terlindungi. Hal ini sangat tergantung bagi negara yang bersangkutan mau memanfaatkannya atau tidak melalui pengembangan sistem HKI yang ada.

Kekayaan alam yang dimiliki oleh Indonesia yang terkait dengan Pengetahuan Tradisional, termasuk di dalamnya: indikasi geografis, ${ }^{7}$ ekspresi foklor ${ }^{8}$ dan sumber daya genetika perlu mendapat perhatian karena merupakan aset yang sangat potensial bagi kemakmuran bangsa. ${ }^{9}$

Konsep "Traditional Knowledge" dapat diterapkan pada bidang pertanian (contoh: subak di Bali), ilmu pengetahuan (obat-obatan tradisional seperti jamu), teknologi (contoh: batik tulis, tempe), pengobatan, termasuk cerita rakyat, indikasi geografis, simbol, dan kekayaan tradisional yang bergerak. Sudah menjadi tradisi dalam kehidupan sehari-hari, di mana masyarakat Indonesia mengenal atau menyebut nama suatu produk barang melalui tempat atau daerah asal barang tersebut, seperti: kopi toraja, ubi cilembu, sarung samarinda, dan lain-lain. Muncul pemahaman bahwa barang-barang tersebut memiliki ciri khas, karakteristik dan kualitas tertentu. Berkaitan dengan Ekspresi folklor merupakan ekspresi budaya tradisional. Jenis-jenis folklor yang tergolong ekspresi, termasuk ke dalamnya segala macam ekspresi seni, dapat digolongkan ke dalam: ungkapan seni musik, ungkapan seni tari, ungkapan seni teater termasuk wayang, ungkapan seni rupa termasuk di dalamnya grafis, lukis, patung, serta gabungan daripadanya termasuk boneka wayang, ungkapan seni sastra, dan upacara adat.

Pemanfaatan sumber daya genetik untuk berbagai kepentingan antara lain sebagai bahan obat, makanan, minuman, pengawet, atau sebagai benih semakin meningkat dengan dukungan perkembangan ilmu di bidang bioteknologi, telah menarik perhatian perusahaan-perusahaan besar tetapi pembagian keuntungan yang adil dan pengalihan teknologi yang sungguh-sungguh dari perusahaan besar tersebut ke negara penghasil/penyuplai sumber daya genetis yang umumnya berasal dari negara berkembang masih belum memadai. ${ }^{10}$

\footnotetext{
${ }^{7}$ Ketentuan mengenai perlindungan hukum terhadap Indikasi geografis diatur dalam UU Nomor 15 Tahun 2001 tentang Merek, dalam Pasal 56-60.

${ }^{8}$ Edi Sedyawati, Menuju Perlindungan \& Pengembangan Ekspersi Folklor: Keterkaitan EF dengan Pengetahuan Tradisional, dalam temu wicara 'Pemberdayaan Sumber Daya Genetik, Pengetahuan Tradisional, dan Ekspresi Folklor, Ditjen HKI, Padang, 8-9 Agustus 2006, hlm. 3. hlm. 105.

${ }^{9}$ Imas Rosidawati, Pengetabuan Tradisional dalam PrespektifHak Kekayaan Intelektual, Unpad Press, 2010, Bandung,

${ }^{10}$ Cita Citrawinda Priapantja, Hak Kekayaan Intelektual Tantangan Masa Depan, Badan Penerbit Fakultas Hukum Universitas Indonesia, Jakarta, 2003, hlm. 37.
} 
Industri yang paling banyak memanfaatkan pengetahuan tradisional adalah pertanian dan farmasi, yang keduanya merupakan industri yang sangat besar. Pada 2006, GNP pertanian dunia diperkirakan mencapai sebesar 1,2 trilyun dollar. Bila sepuluh persennya dianggap merupakan nilai dari pengembangan pengetahuan tradisional diperkirakan mencapai \$ 220 milyar dollar per tahun. Industri farmasi merupakan industri yang sangat besar juga, dengan memperkirakan persentase dari keseluruhan nilai industri didapatkan bahwa nilai tumbuhan alami yang digunakan dalam industri farmasi berkisar dari 400 sampai dengan 900 milyar dollar per tahun. ${ }^{11}$ Dalam kenyataannya lebih dari 120 bahan farmasi yang digunakan secara meluas di dunia berasal dari tumbuhan dan $75 \%$ diantaranya didapatkan dengan mengamati penggunaan tumbuhan tersebut dalam pengobatan tradisional. ${ }^{12}$

Shaman Pharmaceuticals suatu perusahaan farmasi yang berbasis di San Fransisco menamakan pencarian bahan obat baru sebagai "ethnomedically driven drug discovery process" proses pencarian senyawa baru yang dapat dipersingkat dengan pemanfaatan pengetahuan tradisional yang jauh lebih efektif dari "mass screening drug discovery process" karena pembuatan obat baru yang sangat memakan banyak biaya disederhanakan dengan mengambil contoh bahan tanaman yang dipakai oleh dua suku tertentu untuk penyakit yang sama. ${ }^{13}$

Kasus yang terjadi di Indonesia yakni pada tanaman Brotowali dan beberapa tanaman lain yang dipatenkan pihak Jepang. Brotowali sudah lama digunakan sebagai tanaman obat di Indonesia, demikian pula dengan tanaman lain seperti Sambiloto. Berdasarkan observasi internet di website Paten Eropa http.//ep.espacenet.com didapatkan sekitar 40 paten tanaman Indonesia di Kantor Paten Jepang. Perusahaan Sichedo telah mematenkan beberapa ramuan tradisional yang terbuat dari berbagai tanaman dan rempah-rempah. Ramuan-ramuan itu termasuk yang diklaim dapat memperlambat efek penuaan dan menyehatkan rambut, terbuat dari zat-zat yang hanya ditemukan pada cabai jawa. ${ }^{14}$ Indonesia yang memiliki potensi sumber daya hayati dan

\footnotetext{
${ }^{11}$ Claudio Chiarolla, Commodifying Agricultural Biodiversity and Development Related Issues, The Journal Of World Intellectual Property, Volume 9 January 2006, hlm. 27.

${ }^{12}$ Farnsworth, N.R. ; Akerele, O. ; Bingel, A.S. Bulletin World Health Org., 1985, 63, 965-981, dalam Tantono Subagyo, Perlindungan Hukum terhadap Plasma Nutfah dan Pengetahuan Tradisional, Terutama Melalui Konvensi Keanekaragaman Hayati, makalah disampaikan pada Penataran dan Lokakarya (Penlok) Hak Kekayaan Intelektual, Solo, 2007.

${ }^{13}$ Carsten Fink, Paten Protection, Transnational Corporations, and Market Structure: A Simulation Study of the Indian Pharmaceutical Industry, in Intellectual Property and Development Lessons from Recent Economic Research, Oxford University Press, New York, 2005, hlm. 229.

${ }^{14}$ Tim Lindsey dkk, Hak Kekayaan Intelektual, Suatu Pengantar, Alumni, Bandung, 2006, hlm. 64.
} 
pengetahuan tradisional terkait, ternyata belum menikmati secara ekonomi atas hasil dari pemanfaatan sumber daya tersebut.

Negara yang banyak memanfaatkan pengetahuan obat-obatan tradisional Indonesia adalah justru Amerika Serikat dan Jepang. Indonesia yang merupakan pemilik dari keanekaragaman hayati yang dapat dijadikan bahan baku pembuatan obat justru tidak menikmati keuntungan ekonomi. Ketidakadilan dirasakan oleh negara-negara berkembang ketika pengetahuan tradisional bangsa-bangsa di negara berkembang tidak mendapat perlindungan sebagaimana kekayaan intelektual di negara maju, sementara negara-negara maju berupaya sedemikian rupa untuk melindungi kekayaan intelektual dari penyalahgunaan yang terjadi di negara-negara berkembang dengan menekan negara-negara ini untuk melindungi HKI-nya.

Salah satu kelemahan dalam mengembangkan sistem perlindungan terhadap Pengetahuan Tradisional (Traditional Knowledge) adalah sangat terbatasnya data, dokumentasi, dan informasi mengenai Pengetahuan Tradisional yang sebenarnya telah ada sejak ratusan tahun yang lalu. Tidak adanya dokumen tertulis mengenai Pengetahuan Tradisional ini telah menjadi salah satu sebab diberikannya paten oleh kantor paten dengan pertimbangan tidak adanya dokumen pembanding (prior art) yang dapat menggugurkan invensi yang bersangkutan. Hal ini sangat merugikan bagi pihak masyarakat asli / setempat ( indigenous people) selaku pemilik Pengetahuan Tradisional tersebut. ${ }^{15}$

\section{Rumusan Masalah}

Adapun rumusan permasalahan dalam penelitian ini: pertama, bagaimanakah perlindungan hukum Hak Kekayaan Intelektual dalam bidang pengetahuan tradisional mengingat belum ada pengaturan yang khusus dalam perundang-undangan Indonesia; kedua, bagaimanakah konsep pengelolaan pengetahuan tradisional yang berkeadilan dalam mendukung pembangunan ekonomi di Indonesia.

\section{Tujuan Penelitian}

Penelitian ini bertujuan untuk: pertama, menemukan perlindungan hukum Hak Kekayaan Intelektual dalam bidang pengetahuan tradisional; kedua menemukan

${ }^{15}$ Philip Schuler, Biopiracy and Commercialization of Ethnobotanical Knowledge, in: Poor Peoples's Knowledge Promoting Intellectual Property In Developing Countries, J. Michael Fingerand Philip Schuler (ed), A Copublication of the World Bank and Oxford University Press, Washington, 2004, hlm.160. 
konsep pengelolaan pengetahuan tradisional yang berkeadilan dalam mendukung pembangunan ekonomi di Indonesia.

\section{Metode Penelitian}

Penelitian ini menggunakan metode pendekatan yuridis normatif, dan juga metode pendekatan yuridis komparatif. Perbandingan hukum dilakukan mengingat belum ada suatu model law untuk perlindungan pengetahuan tradisional yang seragam di negara-negara berkembang, juga untuk membandingkaan instrumen hukum nasional dan internasional di bidang perlindungan hukum terhadap pengetahuan tradisional, yaitu ketentuan hukum di negara-negara berkembang lainnya seperti Filipina, Cina, dan Australia serta New Zealand untuk model law negara maju.

Spesifikasi penelitian menggunakan deskriptif analisis, yaitu suatu metode penelitian yang bertujuan untuk memberikan gambaran secara sistematis, faktual dan akurat mengenai fakta-fakta, dalam hal ini menganalisis mengenai pentingnya perlindungan hukum terhadap pengetahuan tradisional untuk memperoleh pemahaman yang mendalam, dan untuk mememukan bentuk perlindungan hukum terhadap pengetahuan tradisional yang relevan.

Penelitian ini dilakukan melalui penelitian kepustakaan. Langkah pertama dalam penelitian kepustakaan ini data yang dicari adalah data sekunder untuk memperoleh bahan hukum primer berupa bahan hukum yang mengikat seperti peraturan perundang-undangan nasional, konvensi internasional, perjanjian internasional yang relevan dengan masalah yang dikaji. Bahan hukum sekunder yang meliputi referensi hukum dan non hukum berupa rancangan undang-undang, hasil penelitian, lokakarya, seminar, dan karya tulis dari kalangan hukum dan juga bahan hukum tersier berupa kamus, ensiklopedia dan berbagai artikel di media cetak, dan dari internet.

Langkah selanjutnya melakukan kegiatan penelitian dengan penelusuran teoriteori hukum, yang berkaitan dengan Hak Kekayaan Intelektual, teori keadilan, hukum ekonomi serta kebijakan pemerintah. Kemudian mencermati berbagai peraturan hukum untuk memahami hukum dengan cara mencari kesesuaian asas hukum yang ada yang berkaitan dengan permasalahan dalam penelitian ini. Kemudian melakukan analisis secara deskriptif terhadap hukum positif yang 
berkaitan melalui penalaran teori-teori hukum. Sebagai pendukung data sekunder dilakukan penelitian lapangan dimaksudkan sebagai pelengkap, yaitu untuk mendukung analisis bahan-bahan hukum primer, sekunder dan tersier. Adapun teknik pengumpulan informasi (data hukum) dilakukan dengan cara wawancara mendalam (indepth interview) terhadap para pihak yang berkompeten yang meliputi pejabat-pejabat di Direktorat Jendral HKI Departemen Kehakiman dan Hak Asasi Manusia RI, Departemen Perdagangan dan Industri, Kepala Balai Tanaman Obat, termasuk beberapa ahli HKI dari negara Malaysia.

Teknik pengumpulan data dilakukan dengan mengkaji dan meneliti berbagai sumber data sekunder seperti bahan hukum primer, bahan hukum sekunder dan bahan hukum tersier untuk mendapatkan landasan teoritis, berupa hukum positif, tulisan-tulisan dan pendapat para ahli. Metode analisis data yang digunakan dalam penelitian ini adalah metode normatif kualitatif,, ${ }^{16}$ yaitu berupa pemaparan dan penggambaran secara menyeluruh tentang seluruh masalah yang diteliti, yaitu tentang peraturan perundang-undangan, yang didukung oleh bahan-bahan primer yang diperoleh dari studi lapangan. ${ }^{17}$ Lokasi penelitian dilakukan di Bandung, Lembang, Bogor, Jakarta, Kuala Lumpur - Malaysia, dan Singapura.

\section{Hasil Penelitian dan Pembahasan}

\section{Konsep Perlindungan Pengetahuan Tradisional yang Berkeadilan untuk Mendukung Pembangunan Ekonomi di Indonesia}

Di era perdagangan bebas, banyak negara yang mulai mencari alternatif produk baru untuk diperdagangkan dengan menggali produk-produk yang berbasis pengetahuan tradisional dari negara berkembang yang memiliki kekayaan budaya seperti yang berada di Indonesia untuk dapat diakuisisi serta dikembangkan lebih jauh. Sehingga produk tersebut mampu menguasai pasar dunia tanpa ada kontribusi terhadap negara atau masyarakat pemilik produk tersebut. ${ }^{18}$

Selain itu, faktor budaya juga berpengaruh pada pandangan masyarakat menyangkut nilai ekonomis dari pengetahuan tradisional tersebut. Sama sekali tidak

\footnotetext{
${ }^{16}$ Suharsimi Arikunto, Prosedur Penelitian Suatu Pendekatan Praktek, Rineka Cipta, Jakarta, 2000, hlm. 245.

${ }^{17}$ Deddy Mulyana, Metodologi Penelitian Kualitatif, Rosda, Bandung, 2006, Hlm. 195.

${ }^{18}$ Sudarmanto, Produk Kategori Indikasi Geografis Potensi Kekayaan Intelektual Masyarakat Indonesia, Lembaga Pengkajian Hukum Internasional Fakultas Hukum Universitas Indonesia, Jakarta, 2005, hlm. 109 - 110.
} 
memperhitungkan keuntungan ekonomi dan tidak memiliki keinginan untuk melindungi pengetahuan itu dari pengambilan yang dilakukan oleh orang luar. Hal itu disebabkan oleh adanya anggapan bahwa pengetahuan tersebut adalah milik bersama, memberikan pengetahuan tersebut kepada orang lain dianggap merupakan suatu kebajikan yang akan mendapat balasan di hari kamudian. Kondisi ini jelas sangat rentan terhadap tindakan misappropriation ${ }^{19}$ yang dilakukan oleh peneliti asing untuk pengembangan riset mereka di bidang bioteknologi ataupun farmasi yang lebih banyak dilatarbelakangi motif ekonomi. ${ }^{20}$

Isu-isu di bidang Hak Kekayaan Intelektual dan hak-hak penduduk asli telah menjadi sumber perdebatan dalam beberapa tahun terakhir ini. Perkembangan untuk memecahkan isu-isu sekitar pokok masalah ini tidaklah begitu mudah mengingat rumitnya pokok masalah dan kontradiksi-kontradiksi untuk mengakui bentuk-bentuk HKI sebagai sistem perlindungan yang sudah diakui secara internasional, dan rezim HKI apa yang paling tepat untuk melindungi hak masyarakat lokal Indonesia.

Sejumlah kasus yang dialami oleh negara-negara berkembang, termasuk Indonesia, adalah mengenai penyalahgunaan terhadap sumber daya genetika, dan/ atau yang berhubungan dengan pengetahuan tradisional telah menyoroti kebutuhan dan menekankan urgensi untuk memusatkan perhatian pada isu ini, karena meningkatnya "biopiracy" tanpa persetujuan atau izin dari para pemegang hak dan tanpa adanya keuntungan/kompensasi yang memadai.

Pengetahuan tradisional yang berkaitan dengan Sumber Daya Genetika merupakan tantangan bagi peraturan perundang-undangan di bidang HKI. Argumen yang cenderung muncul yaitu bahwa individu-individu atau perusahaan telah mengambil bahan-bahan Sumber Daya Genetika kepunyaan bersama untuk kepentingan sendiri dan menggunakan bahan-bahan tersebut untuk mengembangkan produk-produk dan memperoleh penghasilan. Pengetahuan tradisional yang berkaitan dengan Sumber Daya Genetik, memiliki nilai ekonomis yang sangat tinggi dalam alam dunia perdagangan dan dapat dikatakan sebagai aset nasional.

${ }^{19}$ Misappropriation diartikan sebagai penggunaan oleh pihak asing dengan mengabaikan hak-hak masyarakat lokal atas pengetahuan tradisional dan sumber daya hayati yang terkait, yang menjadi milik masyarakat yang bersangkutan. Pemahaman ini didasarkan pada pengertian misappropriation yang terdapat dalam Black's Law Dictionary dan pengertian teknis yang terungkap dalam berbagai pertemuan internasional menyangkut perlindungan traditional knowledge, genetic resources dan folklore. Black's Law mengartikan misappropriation sebagai: "the unauthorized, improprer or unlanful use of funds or property for purpose other than that for which intended”. Black's Law Dictionary (9 $9^{\text {th }}$ ed., 2003), hlm. 998.

${ }_{20}$ Agus Sarjono, Hak Kekayaan Intelektual dan Pengetabuan Tradisional, Alumni, Bandung, 2006, hlm. 12. 
Sumber Daya Genetika, Pengetahuan Tradisional dan Pelestarian Sumber Daya Genetik termasuk Indikasi Geografis, kesemuanya saling terkait satu sama lain karena nilai tambah yang diperoleh suatu sumber daya genetika disebabkan oleh Pengetahuan Tradisional yang dimiliki suatu masyarakat. Sebagai contoh: Pengetahuan Tradisional diakui sebagai sarana untuk mempermudah penemuan dan pengembangan obat-obatan yang berasal dari tanaman dan mampu menghemat biaya penelitian yang sangat besar dan waktu yang sangat lama untuk menemukannya, seperti yang tergambar dalam diagram berikut ini:

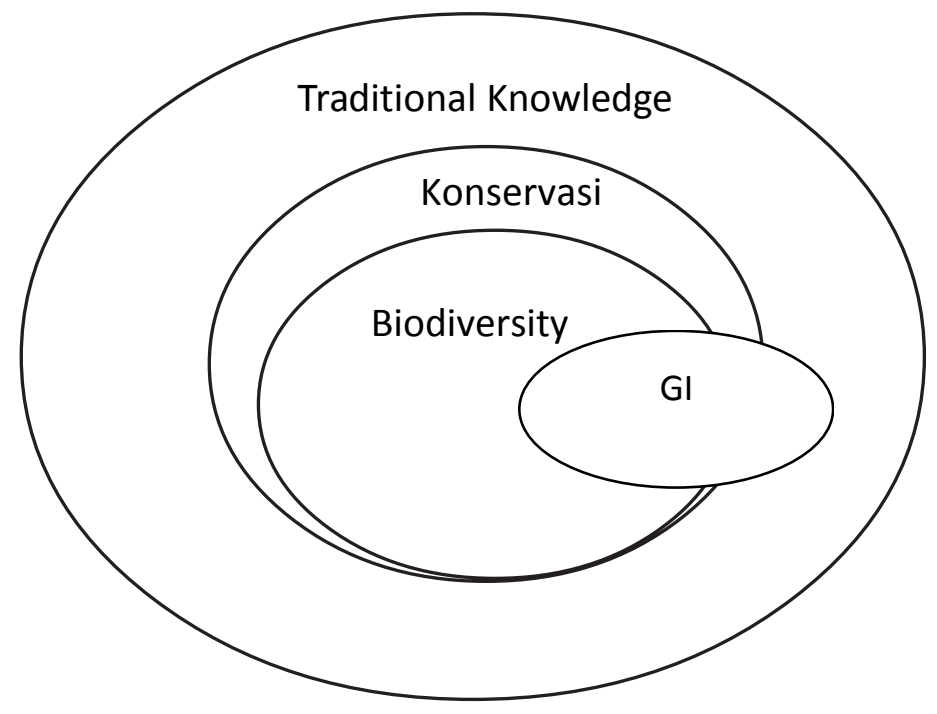

Pada 1997, WIPO membentuk the Global Intellectual Property Issues Division (Global Issues Division). Program yang disiapkan oleh divisi ini bertujuan untuk mengidentifikasi persoalan-persoalan yang berdampak penting terhadap sistem HKI. ${ }^{21}$ Salah satu dari global issue yang berdampak sangat penting terhadap sistem HKI adalah isu mengenai perlindungan pengetahuan tradisional sebagai salah satu bentuk dari intellectual activity in the industrial, scientific, literary or artistic field. ${ }^{22}$

Perbedaan pandangan kedua masyarakat terletak pada konsep dasar dan aspek pemilikannya. Konsep dasar masyarakat Barat yang individual kapitalistik melihat pengetahuan tradisional itu sebagai kekayaan (property) yang dapat dimiliki secara individual, sedangkan masyarakat lokal atau tradisional lebih melihatnya sebagai warisan atau ekspresi kebudayaan (cultural heritage atau cultural expression). Dengan demikian, sebenarnya masih ada peluang untuk menjembatani antara pandangan

\footnotetext{
${ }^{21}$ WIPO, Intellectual Property Needs. (Geneva, 2001), 16.

${ }^{22}$ Pengertian intellectual property yang didefinisikan oleh WIPO mencakup bentuk tersebut, disamping bentuk yang sudah lazim dikenal seperti inventions, industrial design, trademarks copyrights, dan lain-lain. WIPO, Ibid., 15.
} 
masyarakat Barat dan masyarakat tradisional mengenai pengetahuan tradisional sebagai kekayaan intelektual.

Dalam rangka menganalisis mengenai sistem perlindungan atas hak kekayaan intelektual yang dipandang dapat lebih sesuai dengan yang diharapkan/ dibutuhkan oleh masyarakat asli/setempat (indigenous people), dan selaras dengan perkembangan terakhir di bidang sosial, budaya, dan ekonomi. Ada 2 (dua) hal pokok yang dipandang perlu untuk secara seksama ditelaah yaitu: agar pengetahuan tradisional dapat dipertimbangkan sebagai prior art, dan agar perolehan hak kekayaan intelektual (misalnya paten) secara tidak sepantasnya dapat dicegah, ${ }^{23}$ dan dapat lebih mempercepat terealisasinya harapan masyarakat luas yaitu agar pemanfaatan sumber daya genetik, pengetahuan tradisional dan ekspresi folklor dapat dilakukan secara optimal, serta agar tersedia adanya sui generis intellectual property system yang memadai di bidang-bidang tersebut. ${ }^{24}$

Dalam konteks ini pemerintah Indonesia dapat belajar dari pengalaman negaranegara lain, atau bahkan memanfaatkan hasil kerja WIPO atau organisasi internasional lainnya seperti UNEP, yang sudah melakukan berbagai langkah pendahuluan dalam upaya memberikan perlindungan bagi pengetahuan tradisional, dengan penyesuaian yang diperlukan seperti berikut ini: 1 . unsur-unsur/ elements of sui generis intellectual property system for traditional knowledge or expression of folklore, yang diantaranya meliputi: a) pertimbangan/kebijakan yang mendasari diperlukannya sui generis dimaksud; b) subyek yang akan diatur; c) kriteria yang harus dipenuhi oleh subyek dimaksud; d) pemilik; e) hak dan kewajiban apa yang dimiliki oleh pemilik; f) bagaimana prosedur untuk memperoleh hak; g) bagaimana cara mengadministrasikan dan menegakkan hak dimaksud; h) penyelesaian sengketa; i) kapan hak dimaksud berakhir; j) mekanisme pembagian keuntungan dalam perjanjian kontrak yang melibatkan investor asing. 2. dokumentasi mengenai pengetahuan tradisional (dan ekspresi folklor) yang telah ada yang perlu diusulkan untuk dipertimbangkan sebagai prior art. 3. pertukaran informasi mengenai pengetahuan tradisional (dan ekspresi folklor) secara elektronik/on-line, dan 4. menyusun standar dokumentasi hak kekayaan intelektual yang sesuai untuk pengetahuan tradisional (dan ekspresi folklor).

\footnotetext{
${ }^{23}$ Asian - African Forum On Intellectual Property and Traditional Knowledge and Genetic Resources, 18-21 Juni 2007 di Bandung.

${ }^{24}$ Ian F Spellerberg, Biological Diversity, Concerevation and Resource Management, Biodiversity Conservation in Asean Emerging Issues \& Regional Needs, Asean Academic Press, London, Printed and bound in Malaysia 2007, hlm. 7
} 
Dalam rangka melindungi pengetahuan, inovasi dan praktek-praktek tradisional serta kepemilikan sumberdaya oleh masyarakat maka diperlukan perangkat untuk mengatur akses agar ada pembagian keuntungan yang adil dan memadai bagi masyarakat yang secara de facto telah mempraktekkan hal tersebut. Pemerintah saat ini sudah mengesahkan Undang-Undang tentang Pengelolaan Sumber Daya Genetika dengan UU Nomor 4 Tahun 2006 tentang Sumber Daya Genetik untuk Pangan dan Pertanian, sesuai amanat dalam Konvensi Keanekaragaman Hayati. Dengan undang-undang ini diharapkan sumber daya hayati kita dapat terlindungi dari "pencurian" materi genetik maupun pengetahuan lokal (biopiracy) dan mencegah dikembangkannya sumber daya Indonesia menjadi produk industri di luar negeri, tanpa kita mendapat keuntungan daripadanya.

Beberapa alternatif dapat dilakukan pemerintah berkenaan dengan gagasan perlindungan yang dapat diberikan terhadap hak-hak warga masyarakat lokal di Indonesia, seperti membentuk perundang-undangan baru yang bersifat khusus (sui generis) berkenaan dengan persoalan akses orang asing terhadap pengetahuan tradisional Indonesia serta persoalan pembagian manfaat kepada warga masyarakat lokal atas akses dan penggunaan sumber daya tersebut. Tindakan yang juga perlu dilakukan oleh Pemerintah Indonesia adalah merangsang tumbuh kembangnya partisipasi warga masyarakat dalam rangka ikut serta mengupayakan peningkatan pemanfaatan pengetahuan tradisional untuk kesejahteraan warga masyarakat dalam arti luas.

\section{Pembentukan Hukum Sui Generis untuk Pemanfaatan Pengetahuan Tradisional}

Perkembangan hukum merupakan konsekuensi dari perkembangan politik dan ekonomi. Oleh karena itu, pembaharuan hukum harus juga didasarkan pada kebutuhan sosial, ekonomi dan politik. Tetapi di dalam kenyataannya hukum seringkali dipisahkan dari konteks sosialnya.

Pandangan ini realistis karena sebagaimana dikemukakan oleh Lawrence M. Friedman agar hukum dapat bekerja, harus dipenuhi 3 (tiga) syarat: pertama, aturan itu harus dapat dikomunikasikan kepada subjek yang diaturnya; kedua, subjek yang diaturnya mempunyai kemampuan untuk melaksanakan aturan itu; ketiga, subjek itu harus mempunyai motivasi untuk melaksanakan aturan itu. ${ }^{25}$ hlm. 56.

${ }^{25}$ Lawrence M. Friedman, The Legal System A Social Science Respective, Russel Sage Foundation, New York, 1975, 
Atas dasar pandangan-pandangan tersebut dapat dikemukakan bahwa pembaharuan hukum bukan sekadar pembaharuan substansi hukumnya, melainkan pembaharuan orientasi dan nilai-nilai (budaya) yang melandasi aturan hukum tersebut. Dengan kata lain, pembaharuan hukum harus diartikan sebagai mengangkat nilai-nilai hukum yang baru yang hidup dan berkembang dalam masyarakat sebagai akibat adanya perubahan nilai-nilai baru yang hidup dalam masyarakat. Nilai-nilai hukum yang baru inilah yang merupakan landasan filosofis bagi substansi hukum yang baru.

Produk hukum (undang-undang) mengenai pengetahuan tradisional harus dapat direalisir secara yuridis, sehingga ke depan tinggal bagaimana pelaksanaan/ pengejawantahan secara sosiologis di dalam masyarakat yang mencerminkan konsekuensi dari aplikasi produk hukum tersebut. Mengenai hal ini banyak faktor yang saling terkait dalam menciptakan pembentukkan hukum yang tertuang dalam aturan-aturan hukum yang berbentuk undang-undang. Tampaknya penting untuk diciptakan keberadaan aturan hukum.

Pemerintah dapat mempertimbangkan penyusunan perundang-undangan khusus atau sui generis yang di dalamnya mengatur mengenai masalah akses orang asing terhadap sumber daya hayati dan pengetahuan pengetahuan tradisional yang terkait, serta pembagian manfaat yang terjadi karena akses tersebut. Perundangundangan yang sama dapat juga mencantumkan pengaturan mengenai contractual practices and clauses ${ }^{26}$ yang terkait dengan pemberian akses dan pembagian manfaat tersebut di atas.

Sistem Sui Generis diperlukan mengingat rezim HKI yang berlaku sekarang ini telah terbukti kurang sesuai untuk diterapkan dalam melindungi pengetahuan tradisional dari tindakan misappropriation oleh pihak asing. Perlindungan Paten, merek, desain dan sebagainya mungkin efektif untuk melindungi aspek ekonomis dari pengetahuan tradisional. Namun, tidak memadai untuk melindungi sistem pengetahuan tradisional yang bersifat holistik (mencakup aspek spiritual maupun cultural identity or integrity).

Indonesia dapat mempertimbangkan sistem sui generis mengingat karakteristik masyarakat Indonesia yang sangat berbeda dengan masyarakat Barat. Karakteristik masyarakat Indonesia masih diwarnai sistem kolektif atau komunal dan religius,

${ }^{26}$ Patricia Lucia Cantuaria Marin, Providing Protection for Plant Genetic Resources Patents, Sui Generis System, and Biopartnerships, Kluwer Law International, 2002, hlm. 77. 
sehingga perilaku masyarakatnya pun masih diresapi dan dituntun oleh sistem nilai tersebut. Dengan demikian, menciptakan hukum yang berlandaskan sistem nilai yang berbeda hanya akan menimbulkan masalah dalam implementasinya.

Filipina adalah sebuah contoh negara yang telah menciptakan suatu rezim perlindungan pengetahuan tradisional. Misalnya yang dituangkan dalam Section 17 Article 14 Konstitusi mereka sebagai berikut: ${ }^{27}$ "The State shall recognize, respect and protect the rights of the indigenous cultural communities to preserve and develop their cultures, traditions and institution. It shall consider these in the formulation of national plans and policies."

Selanjutnya, ketentuan tersebut dijabarkan dalam Indigenous People Rights Act 1997, yang antara lain memuat ketentuan sebagai berikut: "Indigenous cultural communities/ indigenous peoples have the right to practice and revitalize their own cultural traditions and customs. The state shall preserve, protect and develop the pass, present and future manifestation of their cultures as well as the right to the restitution of cultural, intellectual, religious and spiritual property taken without their free and prior informed consent or in violation of their laws, traditions and customs."

Ketentuan-ketentuan tersebut selain bersifat deklaratif dan memuat aturan normatif, mengatur pula mengenai imbalan bagi masyarakat yang hak-haknya diambil secara paksa atau tanpa izin sebelumnya, atau jika pengambilan itu bertentangan dengan hukum, tradisi dan kebiasaan masyarakat.

Australia mencoba menggunakan hukum adat masyarakat Aborigin bersamasama dengan rezim HKI modern seperti dalam kasus Milpururu vs Indofurn (pty) $L t d .{ }^{28}$ Dalam kasus ini pengadilan Australia menggabungkan sistem Hukum Adat Aborigin dengan sistem HKI. Hukum Adat diterapkan untuk menentukan pemegang hak atas desain tradisional masyarakat Aborigin yang dijadikan desain untuk karpet, sedangkan perlindungannya dilakukan dengan rezim hak Cipta. Apa yang dilakukan oleh pengadilan di Australia memang memungkinkan berdasarkan sistem common law. Dalam sistem ini hakim adalah pembentuk hukum. ${ }^{29}$

Di New Zealand perlindungan pengetahuan tradisional dilakukan melalui sistem prior informed consent (PIC). Pelaksanaan sistem itu dilakukan dalam sistem kerja sama

${ }^{27}$ David Daoas, "Efforts at Protecting Traditional Knowledge: The Experience of Philipines”, Roundtable on Intellectual Property and Traditional Knowledge, (WIPO/IPTK/RT/99/6a, October 27, 1999), 9.

${ }^{28}$ WIPO, Intellectual Property Needs, 64-65. Lihat juga Christine Haight Farley, "Protecting Folklore of Indigenous Peoples: Is Intellectual Property the Answer?”, Connecticut Law Review, (Fall, 1997), 4-7.

${ }^{29}$ Rene David \& John E.C. Brierley, Major Legal Systems in the World Today, $3^{\text {rd }}$ ed.,Stevens \& Sons, London, 1985, 312-313. 
antara masyarakat Maori dengan Cancer Genetics Research Team dari University of Otago. ${ }^{30}$ Sekitar 12.000 anggota masyarakat Maori memberikan berbagai informasi yang diperlukan oleh tim, misalnya mengenai genealogical and medical information. Kerja sama itu kemungkinan paten atas invensi dimiliki secara bersama antara masyarakat Maori dan tim tersebut.

Kerja sama ini (Kimihauora Trust) didukung pula oleh New Zealand Gastroenterologist Association and New Zealand Health Research Council. Dengan demikian, terdapat hubungan yang saling menguntungkan antara masyarakat lokal dan peneliti dengan menerapkan model perlindungan yang melibatkan partisipasi langsung masyarakat dengan memanfaatkan rezim paten.

Di negara-negara lain di kawasan Afrika, Amerika Selatan, dan Asia, WIFOFFMs menemukan berbagai model yang satu sama lain berbeda. ${ }^{31}$ Meskipun demikian, di dalam perbedaan tersebut terdapat unsur yang sama, yaitu bahwa pengetahuan tradisional diperlukan sebagai kekayaan intelektual dalam pengertian yang lebih luas dari pada pengertian konvesional dalam rezim HKI yang sudah dikenal seperti paten, merek, hak cipta atau desain. Itu berarti bahwa memang belum ada satu model law yang seragam menyangkut perlindungan pengetahuan tradisional. Hal ini dapat menjadi peluang bagi Indonesia untuk menerapkan sistem perlindungan yang tepat bagi masyarakat lokal Indonesia. Di sinilah relevansi pertanyaan mengenai rezim apa kiranya yang paling tepat untuk melindungi hak masyarakat lokal ${ }^{32}$ Indonesia berkenaan dengan pengetahuan tradisional.

Substansi yang terpenting dari undang-undang sui generis yang dimaksud adalah adanya pengakuan yang tegas bahwa masyarakat lokal adalah "pemilik" dari pengetahuan tradisional yang bersangkutan. ${ }^{33}$ Hukum adat atau hukum kebiasaan (customary law) dapat menjadi salah satu alternatif sumber atau bahan untuk merumuskan hak-hak masyarakat lokal tersebut di dalam undang-undang sui generis. Prinsip-prinsip dalam hukum adat yang dapat diakomodasi ke dalam undang-undang sui generis antara lain: 1) pengaturan di dalam undang-undang sui generis bersifat sederhana; 2) undang-undang sui generis itu hendaknya tidak mengabaikan unsur-unsur yang berlandaskan pada norma agama. Hal ini sejalan dengan sistem

\footnotetext{
${ }^{30}$ WIPO, Intellectual Property Needs, 76.

${ }^{31}$ WIPO, Intellectual Property Needs, 2001.

${ }^{32}$ Masyarakat lokal mengacu pada kelompok-kelompok masyarakat yang hidup di daerah-daerah di dalam wilayah Indonesia yang biasanya diidentifikasikan sebagai suku bangsa tertentu.

${ }^{33}$ Agus Sarjono, Hak Kekayaan ..., Op. Cit., hlm. 304.
} 
hukum adat yang bersifat magis religius; 3) undang-undang sui generis itu hendaknya tetap berlandaskan kepada sistem kemasyarakatan yang sangat menghargai kebersamaan; 4) undang-undang sui generis itu harus mampu menjamin atau sekurang-kurangnya memberikan kemungkinan yang besar agar pemanfaatan pengetahuan tradisional (termasuk pengetahuan di bidang keanekaragaman hayati) benar-benar dapat memberikan kesejahteraan bagi masyarakat pada umumnya.

Merumuskan cara pandang dan kebiasaan-kebiasaan masyarakat tradisional ke dalam produk undang-undang sui generis yang dimaksud, untuk memberikan perlindungan kepada pengetahuan tradisional. Di sinilah peran para ahli hukum dan lembaga legislatif sangat diharapkan untuk mewujudkan amanat konstitusi dan komitmen Indonesia pasca ratifikasi CBD.

Indonesia juga dapat merujuk pada rumusan WIPO Intergovernmental Committe on Intellectual Property and Genetic Resources, Traditional Knowledge and Folklore (IGCIPGRTKF). Bila ini disepakati, maka beberapa unsur penting yang harus dituangkan dalam undang-undang sui generis antara lain:

Pertama, tujuan dari upaya pemberian perlindungan: a) menciptakan sistem pelestarian, perlindungan, dan pengembangan pengetahuan tradisional; b) melindungi hak-hak pemilik pengetahuan tradisional; c) mengembangkan kapasitas masyarakat pemilik pengetahuan tradisional di Indonesia; d) meningkatkan kemampuan inovasi nasional berbasis pengetahuan tradisional. Dengan demikian, pemberian perlindungan dimaksudkan untuk mencegah terjadinya proses misappropriation oleh pihak asing, juga untuk melindungi dan melestarikan keanekaragaman hayati selain untuk memberikan manfaat ekonomis bagi anggota masyarakat lokal.

Kedua, objek yang dilindungi. Hal/objek yang perlu dilindungi adalah pengetahuan tradisional, mencakup pengetahuan yang: a) dibentuk, dilestarikan, dan disampaikan dalam konteks tradisional antargenerasi; b) memiliki karakteristik khusus berkaitan dengan masyarakat tertentu yang melestarikan dan menyampaikannya antargenerasi; c) terintegrasi dengan budaya masyarakat tertentu melalui kebiasaan yang berlangsung terus menerus. Ketiga, persyaratan atau kriteria untuk mendapatkan perlindungan. Keempat, subjek yang menjadi pengemban haknya. Rezim HKI mensyaratkan adanya individu pencipta atau penemu. Sedangkan dalam sistem pengetahuan tradisional, pencipta atau penemu tidak dapat diidentifikasi secara individual. 
Oleh karena itu, perlu adanya sebuah ketentuan yang menegaskan siapa yang dimaksud komunitas atau masyarakat sebagai pengemban hak dari pengetahuan tradisional yang bersangkutan. ${ }^{34}$ Subjek pengetahuan tradisional adalah pemegang hak pengetahuan tradisional, dalam hal ini adalah masyarakat tradisional yang memelihara dan mengembangkan pengetahuan tradisional dan ekspresi budaya tradisional secara tradisional dan komunal. Menyampaikan pengetahuan tersebut dari generasi ke generasi sebagai pemilik hak pengetahuan tradisional, atau pihak yang menerima hak tersebut dari pemilik hak pengetahuan tradisional. Pihak yang menerima hak tersebut dari pemilik hak pengetahuan tradisional dapat terdiri dari: a) pemerintah pusat; b) pemerintah daerah; c) pihak lain yang memperoleh hak pengetahuan tradisional berdasarkan ketentuan-ketentuan yang berlaku, misalnya melalui lisensi; d) negara memegang hak pengetahuan tradisional yang tidak diketahui pemiliknya.

Apabila terdapat kesulitan untuk mengidentifikasi masyarakat tertentu yang menjadi subjek atau pemilik suatu pengetahuan tradisional tertentu (misalnya karena pengetahuan yang bersangkutan dimiliki secara bersama oleh berbagai kelompok masyarakat lokal), maka komunitas atau masyarakat itu dapat digantikan kedudukannya oleh negara. ${ }^{35}$ Undang-undang Hak Cipta telah menggunakan model ini dengan menetapkan negara sebagai pemegang hak cipta atas ekspresi folklore. Dalam hal hukum kebiasaan masyarakat (customary law) membuka kemungkinan untuk memberikan pengakuan terhadap hak-hak individual atas pengetahuan tradisional, maka kemungkinan itu harus diakomodasi pula ke dalam undangundang yang dimaksud.

Kelima, hak yang dimiliki oleh pemilik. Dalam undang--undang sui generis harus ada kejelasan bahwa pengetahuan tradisional merupakan hak eksklusif bagi masyarakat pemilik pengetahuan tradisional untuk mengumumkan dan/atau memanfaatkan pengetahuan tradisional yang dimilikinya, dengan lingkup antara lain: a) pemegang hak pengetahuan tradisional berhak untuk mengelola pengetahuan tradisional dengan memperhatikan praktik dan kebiasaan yang berlaku di masyarakat setempat; b) pemegang hak pengetahuan tradisional berhak untuk memperoleh perlindungan dari klaim yang menyesatkan atas kepemilikan pengetahuan tradisional; c) pemegang hak pengetahuan tradisional berhak untuk memperoleh perlindungan dari perolehan dan penggunaan pengetahuan tradisional tanpa izin; d) pemegang hak pengetahuan

\footnotetext{
${ }^{34}$ Joseph Wambugu, Ibid., hlm. 44.

35 Joseph Wambugu, Ibid., hlm. 46.
} 
tradisional berhak untuk memperoleh pembagian manfaat dan keuntungan yang adil atas penggunaan pengetahuan tradisional untuk kepentingan komersil pihak lain.

Berkaitan dengan isi hak, dalam rezim hak cipta misalnya dikenal dengan dua macam hak yang dilindungi, yaitu economic rights dan moral rights. Analog dengan konsep hak tersebut, substansi hak atas pengetahuan tradisonal juga dapat dilihat dalam konteks ini. Economic rights dari masyarakat lokal menyangkut kepentingan masyarakat untuk memperoleh manfaat ekonomis dari penggunaan pengetahuan tradisional yang bersangkutan.

Keenam, prosedur/cara memperoleh hak atas pengetahuan tradisional. Dalam rezim HKI, persoalan mengenai perolehan hak atas kekayaan intelektual terbagi dalam dua kelompok. Dalam rezim hak cipta, hak diperoleh secara otomatis tanpa harus melakukan permohonan hak sebagaimana rezim paten dan merek dagang. Dengan kata lain bahwa HKI mengenal dua sistem perolehan hak, yaitu sistem otomatis sebagaimana hak cipta dan sistem permohonan dan pendaftaran sebagaimana hak paten dan hak merek.

Dalam sistem pengetahuan tradisional kiranya tidak dikenal sistem perolehan hak tersebut. Hal ini disebabkan oleh karakter dari pengetahuan tradisional itu sendiri yang tidak mengenal subjek pemilikan individu. Di samping itu, pengetahuan tradisional berkembang dan dipraktikkan oleh anggota masyarakat dari generasi ke generasi. Dengan kata lain, hak masyarakat atas pengetahuan tradisional sudah ada dengan sendirinya seiring dengan berkembangnya pengetahuan itu di tengah masyarakat yang bersangkutan. Mekanisme yang dapat diterapkan dalam memperoleh hak atas pengetahuan tradisional antara lain melalui: a) proses registrasi/pendaftaran pengetahuan tradisional dari dokumentasi yang telah dilakukan ke kantor HKI (Direktorat Jenderal Hak Kekayaan Intelektual), dalam suatu Daftar Umum Pengetahuan Tradisional Indonesia. Namun, yang perlu dicatat adalah bahwa dokumentasi itu bukanlah cara untuk memperoleh hak atas pengetahuan tradisional, melainkan sebuah upaya untuk mempermudah pembuktian bahwa pengetahuan tradisional tertentu adalah milik masyarakat tertentu; b) Daftar Umum Pengetahuan Tradisional Indonesia tersebut dapat ditempatkan dalam media yang mudah diakses dan dapat dilihat oleh setiap orang tanpa dikenakan biaya; c) setiap orang dapat memperoleh untuk dirinya sendiri suatu petikan dari Daftar Umum Pengetahuan Tradisional Indonesia tersebut dengan dikenakan biaya; d) pendaftaran pengetahuan tradisional dalam Daftar Umum 
Pengetahuan Tradisional Indonesia dilakukan atas prakarsa instansi pemerintah yang berwenang, seperti Ditjen HKI bidang pendayagunaan sumber daya genetika, pengetahuan tradisional, dan ekspresi folklor; Kementerian Ristek \& BPPT; Pemerintah Daerah setempat, dan Departemen Kesehatan; e) pendaftaran dapat juga diajukan oleh masyarakat dan/atau perwakilannya atau pemerintah daerah setempat kepada instansi yang berwenang, seperti Kesatuan Budaya Masyarakat tertentu; f) adanya batas waktu tertentu untuk pengajuan permohonan pendaftaran pengetahuan tradisional dimaksud.

Pihak-pihak yang ingin melakukan akses terhadap pengetahuan tradisional wajib mengajukan permohonan izin akses kepada instansi yang berwenang, termasuk warga negara asing yang akan melakukan akses terhadap pengetahuan tradisional wajib bekerjasama dengan lembaga nasional di bidang penelitian dan pengembangan yang ditunjuk oleh yang berwenang. Berkenaan dengan pemanfaatan pengetahuan tradisional secara komersial harus ada persetujuan dari instansi pemerintah yang berwenang, dengan memperhatikan hal-hal berikut: a) komersialisasi pengetahuan tradisional oleh pihak asing harus dilakukan dengan membentuk konsorsium antara pihak asing dengan mitra pendamping dari dalam negeri; b) izin komersialisasi pengetahuan tradisional oleh pihak asing disertai dengan pembayaran royalti, yang besarnya ditetapkan berdasarkan kesepakatan antara pihak asing dan komunitas dengan memperhatikan kepentingan yang wajar dari masyarakat pemilik pengetahuan tradisional.

Ketujuh, penyelesaian sengketa. Dalam praktek kemungkinan besar terdapat pengetahuan tradisional terkait dengan pemanfaatan sumber daya hayati yang bersifat lintas batas negara atau terdapat pengetahuan serupa di suatu kawasan tertentu, sehubungan dengan hal itu perlu dicari suatu mekanisme baik ditingkat nasional ataupun regional untuk mengakomodasi permasalahan lintas batas dalam hal pemanfaatan pengetahuan tradisional kaitannya dengan keanekaragaman hayati termasuk sumber daya genetika di dalamnya. Contoh mekanisme semacam ini misalnya terdapat dalam Sistem Pakta Andean diantara negara-negara Amerika Latin; Nordic Council of Ministyers di antara negara Swedia, Norwegia, dan Finlandia; dan Draf ASEAN Framework Agreement on Access E Benefit Sharing. ${ }^{36}$ Untuk penyelesaian

${ }^{36}$ Dikemukakan dalam forum "Expert Group on Traditional Knowledge Associated with Genetic Resources" yang diselenggarakan di India pada tanggal 16-19 Juni 2009, forum ini dihadiri oleh perwakilan Argentina, Australia, Austria, Brazil, Canada, China, Costarica, Mesir, Georgia, Jerman, Ghana, Guatemala, India, Indonesia, Malaysia, Mexico, Norwegia, Philipina, Federasi Rusia, Swedia, Tajkistan, dan Uzbekistan. Forum ini juga dihadiri oleh pengamat (observers) yang mewakili masyarakat asli dan lokal, seperti Indigenous Information Network, Saami Council, dan South West Aboriginal. Pengamat lainnya dari International Chamber of Commerce (ICC) dan WIPO. 
sengketa yang mungkin terjadi dalam hal pemanfaatan pengetahuan tradisional yang terkait dengan kenakekaragaman hayati termasuk sumber daya genetika, ada baiknya dibentuk mekanisme arbitrase atau alternatif penyelesaian sengketa dan juga institusi semacam "Ombudsman/ombudsperson", yang merupakan penyelesaian sengketa di luar pengadilan.Lembaga-lembaga semacam ini diharapkan dapat menyelesaikan sengketa yang mungkin timbul dari pemanfaatan pengetahuan tradisional yang bersifat lintas batas dan mengatasi ketidakseimbangan yang seringkali terjadi antara pemohon akses dan masyarakat pemilik pengetahuan tradisional. Penyelesaian sengketa antara pemilik pengetahuan tradisional dan pihak lain, dapat juga diselesaikan melalui pengadilan, apabila diperjanjikan demikian dengan mengajukan gugatan ke pengadilan negeri setempat, dengan mengajukan gugatan ganti rugi, dan/atau penghentian semua perbuatan yang berkaitan dengan pemanfaatan tersebut.

Kedelapan, penegakkan undang-undang sui generis yang melindungi pengetahuan tradisional. Perlindungan pengetahuan tradisional tidak berarti apaapa manakala hukum atau undang-undang yang melindungi pengetahuan tersebut tidak dapat dilaksanakan atau tidak dapat ditegakkan dengan efektif. Salah satu unsur yang memungkinkan untuk adanya penegakan yang efektif adalah apabila di dalam undang-undang itu terdapat sanksi hukum seperti ganti rugi atau kompensasi atas pelanggaran hak yang bersangkutan atau dengan menerapkan ketentuan pidana. Dalam sistem pengetahuan tradisional di Indonesia, mungkin agak sulit untuk mengharapkan masyarakat lokal secara aktif melakukan upaya law enforcement, tindakan aktif sebaiknya dilakukan oleh pemerintah.

Kesembilan, berakhir dan cara bagaimana hak itu berakhir. Berbeda dengan rezim HKI, hak atas pengetahuan tradisional yang dimiliki oleh masyarakat bukanlah hak yang sifatnya dibatasi jangka waktu. Hak pengetahuan tradisional dilindungi selamanya tanpa adanya batasan waktu. Dengan demikian, persoalan mengenai jangka waktu perlindungan menjadi tidak relevan untuk ditetapkan dalam undangundang sui generis.

\section{Penutup}

Berdasarkan uraian di atas dapat disimpulkan: pertama, perlindungan Hak Kekayaan Intelektual terhadap pengetahuan tradisional dengan memanfaatkan UU Hak Kekayaan Intelektual belum sepenuhnya dapat memberikan perlindungan. Hal ini disebabkan karakteristik dari HKI sendiri yang berbeda dengan pengetahuan 
tradisional. Dalam perlindungan HKI sesuai dengan sifatnya yang eksklusif, monopolis, individualistis sehingga bersifat privat domain sangat berbeda dengan sifat pengetahuan tradisional yang mengusung paham kolektifisme. Bagi negara Indonesia pengetahuan tradisonal merupakan aset nasional yang tak ternilai, oleh karena itu harus dilindungi dan dilestarikan. Perlindungan hukum tidak saja untuk menghindari persaingan tidak sehat dengan adanya misappropriation tetapi juga bermanfaat untuk pemerataan dan pembangunan ekonomi. Kedua, konsep pengelolaan Pengetahuan Tradisional bidang keanekaragaman hayati yang tepat adalah dengan membuat undang-undang yang bersifat sui generis berdasarkan pada tradisi yang berkembang di tengah masyarakat lokal. Perlindungan dimaksudkan untuk peningkatan kesejahteraan masyarakat, tidak hanya untuk tujuan kemanusiaan sebagaimana pandangan masyaarakat asli, tetapi diarahkan untuk peningkatan kesejahteraan ekonomi dari setiap anggota masyarakat, melalui akses yang diberikan kepada perusahaan asing atau pihak-pihak luar lainnya dengan adanya benefit sharing yang berkeadilan dan diterima oleh masyarakat sebagai pemilik dari pengetahuan tradisional tersebut .

Selain perlu dilindungi oleh hukum, pengelolaan pengetahuan tradisional juga membutuhkan langkah-langkah pengembangan sehingga dapat menjadi aset potensial suatu daerah. Langkah-langkah pengembangan ini dapat dilaksanakan sesuai dengan peraturan perundang-undangan yang berlaku. Di samping itu, pengembangan pengetahuan tadisional juga membutuhkan mekanisme kelembagaan yang kuat yang tetap memperhatikan kepentingan kelompok masyarakat yang berkepentingan.

Dalam konteks perlindungan pengetahuan tradisional pembentukan perlindungan hukum itu harus diikuti dengan pembentukan perangkat yang akan mempertahankan hak-hak masyarakat lokal Indonesia terhadap pelanggaran hak oleh pihak asing. Perlu adanya keterpaduan pendekatan hukum nasional dan hukum internasional, dengan asumsi isu hukum berkaitan pengelolaan Pengetahuan Tradisional bersifat lintas batas negara. Pemerintah juga perlu menetapkan langkahlangkah yang lebih konkrit dalam rangka memperkuat posisi negoisasi di tingkat internasional. 


\section{Daftar Pustaka}

Achmad Zen Purba, Hak Kekayaan Intelektual Pasca TRIPs, Alumni, Bandung, 2005.

Agus Sarjono, Hak Kekayaan Intelektual dan Pengetahuan Tradisional, Alumni, Bandung, 2006.

, Membumikan HKI di Indonesia, Nuansa Aulia, Bandung, 2009.

Cita Citrawinda Priapantja, Budaya Hukum Indonesia Menghadapi Globalisasi Perlindungan Rahasia Dagang Di Bidang Farmasi, Chandra Pratama, Jakarta, 2005.

, Hak Kekayaan Intelektual Tantangan Masa Depan, Badan Penerbit Fakultas Hukum Universitas Indonesia, Jakarta, 2003.

Carsten Fink, Paten Protection, Transnational Corporations, and Market Structure : A Simulation Study of the Indian Pharmaceutical Industry, in Intellectual Property and Development Lessons from Recent Economic Research, Oxford University Press, New York, 2005.

Claudio Chiarolla, Plant Patenting, Benefit Sharing and the Law Applicable to the Food and Agriculture Organisationb Standard Material Transfer, The Journal OfWorld Intellectual Property, Blackwell Publishing Ltd, Volume 11 Number 1 Januari 2008.

, Commodifying Agricultural Biodiversity and Development Related Issues, The Journal Of World Intellectual Property, Volume 9 January 2006.

Christopher May, The World Intellectual Property Organization Resurgence and the Development Agenda, Routledge Taylor \&Francis Group, London and New York, 2006.

David Daoas, "Efforts at Protecting Traditional Konwledge: The Experience of Philipines", Roundtable on Intellectual Property and Traditional Knowledge, (WIPO/IPTK/RT/99/6a, October 27, 1999.

Deddy Mulyana, Metodologi Penelitian Kualitatif, Rosda, Bandung, 2006.

Edi Sedyawati, "Menuju Perlindungan \& Pengembangan Ekspersi Folklor: Keterkaitan EF dengan Pengetahuan Tradisional", dalam temu wicara Pemberdayaan Sumber Daya Genetik, Pengetauan Tradisional, dan Ekspresi Folklor, Ditjen HKI, Padang, 8-9 Agustus 2006.

Farnsworth, N.R. ; Akerele, O. ; Bingel, A.S. Bulletin World Health Org, 1985

Ian F Spellerberg, Biological Diversity, Concerevation and Resource Management, Biodi versity Conservation In Asean Emerging Issues \& Regional Needs, Asean Academic Press, London, Printed and bound in Malaysia, 2007.

Imas Rosidawati, Pengetahuan Tradisional dalam Prespektif Hak Kekayaan Intelektual, Unpad Press, Bandung, 2010.

James S Miller, Impact of the Convention on Biological Diversity: The Lesson of Ten Years of Experience with Models for Equitable Sharing of Benefits, Biodiversity Law Intellectual 
Biotechnology Traditional, Edited by Charles R. McManis, Earthscan Sterling, VA, London, 2007.

Lawrence M. Friedman, The Legal System A Social Science Respective, Russel Sage Foundation, New York, 1975.

Kerry ten Kate and Sarah A. Laird, Bioprospecting Agreements and Benefit Sharing with Local Communities, in: Poor Peoples's Knowledge Promoting Intellectual Property In Developing Countries, J. Michael Fingerand Philip Schuler (ed), A Copublication of the World Bank and Oxford University Press, Washington, 2004.

Ranti Fauza Mayana, Perlindungan Desain Industri Di Indonesia Dalam era Perdagangan Bebas, Grasindo, Jakarta, 2004.

Rene David \& John E.C. Brierley, Major Legal Systems in the World Today, $3^{\text {rd }} e d$, Stevens \& Sons, London, 1985.

Sarah A. Laird \& Kerry Ten Kate, " Biodiversity prospecting : The commercial use of genetic resources and best practice in benefit sharing, dalam Sarah A., Laird (ed.), Biodiversity and Traditional Knowlledge - Equitable Partnershps in Practice, Earthscan, London, 2002.

Sudarmanto, Produk Kategori Indikasi Geografis Potensi Kekayaan Intelektual Masyarakat Indonesia, Lembaga Pengkajian Hukum Internasional Fakultas Hukum Universitas Indonesia, Jakarta, 2005.

Sudjana, Perlindungan Desain Tata Letak Sirkuit Terpadu Dihubungkan dengan Daya Saing Industri Elektronika Pada Era Perdagangan Bebas, disertasi, Universitas Padjadjaran, Bandung, 2006.

Suharsimi Arikunto, Prosedur Penelitian Suatu Pendekatan Praktek, Rineka Cipta, Jakarta, 2000.

Patricia Lucia Cantuaria Marin, Providing Protection for Plant Genetic Resources Patents, Sui Generis System, and Biopartnerships, Kluwer Law International, 2002.

Philip Schuler, Biopiracy and Commercialization of Ethnobotanical Knowledge, in : Poor Peoples's Knowledge Promoting Intellectual Property In Developing Countries, J. Michael Fingerand Philip Schuler (ed), A Copublication of the World Bank and Oxford University Press, Washington, 2004.

Tim Lindsey dkk, Hak Kekayaan Intelektual, Suatu Pengantar, Alumni, Bandung, 2006.

WIPO, Intellectual Property Needs and Expectation of Traditional Knowledge Holders: WIPO Reeport on Fact-finding Missions oon 23-26

Undang - Undang Dasar 1945

Undang-Undang Nomor 5 Tahun 1994 tentang Pengesahan United Nations Convention on Biological Diversity

Undang-Undang Nomor 7 Tahun 1994 tentang WTO

Undang-Undang Nomor 15 Tahun 2001 tentang Merek

Undang-Undang Nomor 14 Tahun 2001 tentang Hak Paten 
Undang-Undang Nomor 19 Tahun 2002 tentang Hak Cipta

Undang-Undang Nomor 21 Tahun 2004 tentang Pengesahan Cartagena Protocol On Biosafety To The Convention On Biological Diversity

Undang-Undang Nomor 4 Tahun 2006 tentang Perjanjian Mengenai Sumber Daya Genetika Tanaman Untuk Pangan dan Pertanian

Peraturan Presiden Republik Indonesia Nomor 21 Tahun 2005 tentang Keanekaragaman Hayati Produk Rekayasa Genetika. 